\title{
Glucagon-Like Peptide-1
}

\author{
Máire E. Doyle and Josephine M. Egan \\ Diabetes Section, National Institute on Aging, National Institutes of Health, \\ 5600 Nathan Shock Drive, Baltimore, Maryland 21224
}

\begin{abstract}
There is a progressive impairment in beta-cell function with age. As a result, 19 percent of the U.S. population over the age of 65 is diagnosed with type 2 diabetes mellitus (DM). Glucagon-like peptide-1 (GLP-1) is a potent insulin secretagogue that has multiple synergetic effects on the glucosedependent insulin secretion pathways of the $\beta$-cell. This peptide and its longer-acting analog exendin- 4 are currently under review as treatments for type $2 \mathrm{DM}$. In our work on the rodent model of glucose intolerance in aging, we found that GLP-1 is capable of rescuing the age-related decline in $\beta$-cell function. We have shown that this is due to the ability of GLP-1 to 1) recruit $\beta$-cells into a secretory mode; 2 ) upregulate the genes of the $\beta$-cell glucose-sensing machinery; and 3 ) cause $\beta$-cell differentiation and neogenesis.

Our investigations into the mechanisms of action of GLP-1 began by using the reverse hemolytic plaque assay to quantify insulin secretion from individual cells of the RIN 1046-38 insulinoma cell line in response to acute treatment with the peptide. GLP-1 increases both the number of cells secreting insulin and the amount secreted per cell. This response to GLP-1 is retained even in the $\beta$ cell of the old (i.e., 22-month), glucose-intolerant Wistar rat, which exhibits a normal, first-phase insulin response to glucose following an acute bolus of GLP-1. Preincubation with GLP-1 (24 hours) potentiates glucose- and GLP-1-dependent insulin secretion and increases insulin content in the insulinoma cells. Treatment of old Wistar rats for $\mathbf{4 8}$ hours with GLP-1 leads to normalization of the insulin response and an increase in islet insulin content and mRNA levels of GLUT 2 and glucokinase. PDX-1, a transcriptional factor activator of these three genes, also is upregulated in the insulinoma cell line in aged rats and diabetic mice following treatment with GLP-1. Administration of GLP-1 to old rats leads to pancreatic cell proliferation, insulin-positive clusters, and an increase in $\beta$-cell mass. This evidence led us to believe that GLP-1 is an endocrinotrophic factor. We used an acinar cell line to show that GLP-1 can directly cause the conversion of a putative pro-endocrine cell into an endocrine one. 'Thus, the actions of GLP-I on the $\beta$-cell are complex, with possible benefits to the diabetic patient that extend beyond a simple glucose-dependent increase in insulin secretion. The major limitation to GLP-1 as a clinical treatment is its short biological half-life. We have shown that the peptide exendin-4, originating in the saliva of the Gila monster, exhibits the same insulinotropic and endocrinotrophic properties as GLP-1 but is more potent and longer acting in rodents and humans.
\end{abstract}

\section{Introduction}

Type 2 diabetes mellitus (DM) is one of the most-prevalent metabolic disorders in the United States. Almost 6 percent of the population carries the diagnosis 
(Centers for Disease Control and Prevention, 1998), while approximately another three percent are estimated to be unaware that they have the condition (Harris et $a l ., 1998)$. It results from a failure of the $\beta$-cell to produce sufficient insulin to meet the demands of the body. Medications currently in use have limited success in controlling blood glucose levels, hence, the complications of the disease (United Kingdom Prospective Diabetes Study, 1998). An ongoing failure in $\beta$-cell function is another aspect of this disease that none of the currently used medications is capable of reversing (United Kingdom Prospective Diabetes Study, 1995). The Diabetes Section at the National Institute on Aging (NIA) became interested in glucagon-like peptide-1 (GLP-1) as a treatment for diabetes when it was reported to effectively lower blood glucose levels in diabetic subjects (Nathan et al., 1992; Gutniak et al., 1992). We set out to investigate its mechanisms of action and to develop its potential and that of agonists at the GLP-1 receptor as treatments for type $2 \mathrm{DM}$. In both instances, we have placed a special emphasis on the aged diabetic condition.

\section{Background}

GLP-1 is secreted by intestinal L-cells in response to nutrient ingestion (Mojsov et al., 1986). Exogenous administration of GLP-1 reduces blood glucose levels in both normal and diabetic subjects (Nathan et al., 1992) by stimulating insulin secretion and synthesis in concert with glucose (Fehmann et al., 1992) and by suppressing glucagon secretion (Komatsu et al., 1989). (For a more-comprehensive review of glucagon-like peptides, see Fehmann et al., 1995, and Drucker, 1998. This chapter will confine its background discussion to effects on acute insulin secretion.)

GLP- 1 action in the $\beta$-cell is mediated by binding of the peptide to a specific, seven-membered transmembrane receptor (Thorens et al., 1993). Activation of this G-coupled receptor causes an increase in intracellular cAMP concentration (Drucker et al., 1987) and activation of protein kinase A (PKA). GLP-1 acts directly through the cAMP/PKA pathway to enhance and sensitize $\beta$-cells to glucose-stimulated insulin secretion (Figure 1). The metabolism of glucose in the $\beta$-cell causes an increase in the amount of adenosine triphosphate (ATP) and a rise in the cytoplasmic ATP:adenosine diphosphate (ADP) ratio, leading to closure of the $\mathrm{K}_{\mathrm{ATP}}$ channels. GLP-1 may close the $\mathrm{K}_{\mathrm{ATP}}$ channels via a PKA-mediated phosphorylation. These channels possess sites that are phosphorylated by G-protein stimulated PKA (Béguin et al., 1999). The ability of the specific PKA inhibitor Rp-cAMP to reverse the GLP-1 action on the $\mathrm{K}_{\mathrm{A} \text { TP }}$ channels confirms the involvement of PKA in this step (Holz et al., 1993).

Subsequent membrane depolarization results in the activation of voltage-dependent L-type $\mathrm{Ca}^{2+}$ channels, an influx of $\mathrm{Ca}^{2+}$, and exocytosis of the insulin- 


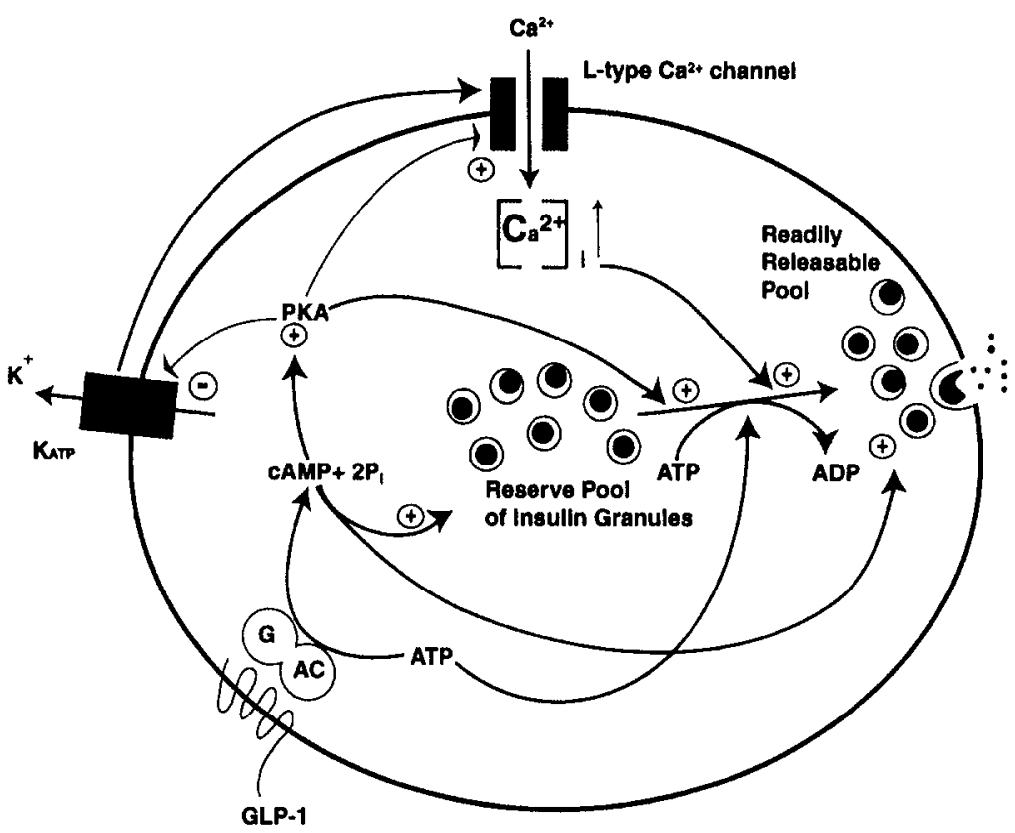

FIG 1. Known intercellular events that occur upon binding of GLP-1 to its specific G-coupled protein receptor. Adenylyl cyclase is activated, with a consequential rise in cAMP that, in turn, results in PKA activation. Then, by PKA-dependent and -independent means, insulin release results.

containing granules. GLP-1 is known to cause a rise in intracellular $\mathrm{Ca}^{2+}$ concentration $\left[\mathrm{Ca}^{2+}\right]_{i}$ (Yada et al., 1993). This effect is attributable both to greater activation of the L-channel, which could be due to its phosphorylation by PKA, and also to a mobilization of the intercellular stores of $\mathrm{Ca}^{2+}$, which may or may not be PKA dependent (Bode et al., 1999). GLP-1 also increases insulin secretion in a calcium-independent manner by mobilizing secretory vesicles to enter the readily releasablc pool. Again, this is by both PKA-dependent and -independent means (Gromada et al., 1998).

\section{GLP-1 Acute Effects on Insulin Secretion in Vitro}

GLP-1 enhances glucose-dependent insulin secretion in the insulinoma cell line RIN 1046-38 (Montrose-Rafizadeh et al., 1994). The presence of GLP-1 (10 $\mathrm{nM}$ ) decreases the concentration of glucose required for half-maximal insulin secretion ( 0.72 vs. $0.19 \mathrm{mM}$, control vs. treated). During the course of a 1-hour static insulin-release experiment, the total amount of insulin secreted en masse is increased by the addition of GLP-1 $(10 \mathrm{nM})$ from 10.33 to $25.18 \mathrm{ng}$ insulin $/ \mathrm{mg}$ 
protein/hour. This occurs as GLP-1 increases 1) the amount of insulin secreted per cell and 2) the number of cells that are responsive to glucose. This has been demonstrated by the use of the reverse hemolytic plaque assay, the only means of determining both the relative amount of insulin secreted by an individual $\beta$-cell and the percentage of cells secreting insulin (Egan et al., 1991).

\section{A. INCREASE IN THE AMOUNT OF INSULIN SECRETED}

Under conditions of maximal glucose stimulation, the addition of GLP-1 results in a 1.3-fold increase in the relative amount of insulin secreted per cell (Table I, compare conditions 5 and 6). Priming the cells by adding potassium (20 $\mathrm{mM}$ ) results in membrane depolarization and the secretion of insulin, even in the absence of glucose. That the glucose requirement for GLP-1 action can be replaced by cell membrane depolarization (condition 5 vs. 7) suggests that a rise of intracellular $\mathrm{Ca}^{2+}$ may be an early step required for GLP-1 action. When GL.P-1

TABLE I

Insulin Secretion from Single RIN 1046-38 Cells, Measured by Reverse Hemolytic Plaque Assay

\begin{tabular}{llllll}
$\begin{array}{l}\text { Condi- } \\
\text { tion }\end{array}$ & $\begin{array}{l}\text { Glucose } \\
(\mathrm{mM})\end{array}$ & $\begin{array}{l}\mathrm{KCl} \\
(\mathrm{mM})\end{array}$ & $\begin{array}{l}\text { GLP-1 } \\
(\mathrm{nM})\end{array}$ & $\begin{array}{l}\text { Percent of } \\
\text { Secreting Cells }\end{array}$ & $\begin{array}{l}\text { Mean Plaque Area } \\
\left(\mu \mathrm{m}^{2)}\right.\end{array}$ \\
\hline 1 & 0 & 0 & 0 & $12.5 \pm 1.5$ & $\mathrm{ND}$ \\
2 & 0 & 0 & 10 & $14.7 \pm 1.1$ & $\mathrm{ND}$ \\
3 & 0 & 20 & 0 & $41.2 \pm 1.4$ & $506 \pm 29$ \\
4 & 0 & 20 & 10 & $67.6 \pm 1.3$ & $2185.9 \pm 111.2$ \\
5 & 20 & 0 & 0 & $55.9 \pm 3.3$ & $1586.5 \pm 86.2$ \\
6 & 20 & 0 & 10 & $83.5 \pm 1.2$ & $1990.8 \pm 88.4$ \\
7 & 20 & 20 & 0 & $93.8 \pm 1.2$ & $3076.1 \pm 124.5$ \\
8 & 20 & 20 & 10 & $92.7 \pm 10.9$ & $4825.0 \pm 194.5$ \\
\hline
\end{tabular}

Insulin secretion from individual cells and the number of cells secreting insulin were measured by the reverse hemolytic plaque assay in either normal $\mathrm{K}^{+}(5 \mathrm{mM} \mathrm{KCl})$ or high $\mathrm{K}^{+}(20 \mathrm{mM} \mathrm{KCl}$; i.e., membrane depolarization), in the presence or absence of $20 \mathrm{mM}$ glucose and in the presence or absence of $10 \mathrm{nM}$ GLP-1. The percentage of cells with plaques (cells secreting insulin) was quantified by counting 50-60 cells in each treatment group. Plaque area was measured as described in 15-20 cells in each treatment group. Results are presented as the mean \pm S.E. of measurements from three independent cell preparations. ND, not determined because plaques were too small for reliable measurements. [Adapted with permission from Montrose-Rafizadeh, C., Egan, J.M., and Roth, J Endocrinology 135, 589-594, 1994. Copyright The Endocrine Society.] 
is added to the combination of glucose and membrane depolarization, there is no additional increase in the number of cells secreting insulin but there is a 1.6-fold increase in the relative amount of insulin secreted per cell (compare conditions 7 and 8).

The increase in the amount of insulin secreted by the $\beta$-cell can be attributed to the action of GLP-1-stimulated second messengers on the process of exocytosis of the insulin granules (Figure 1). GLP-1 accelerates insulin secretion by stimulating exocytosis of the readily releasable pool of insulin granules. These are the granules close to the surface of the $\beta$-cell. Their release is stimulated by the action of cAMP (Renström et al., 1997). Pretreatment of RIN cells with the cAMP analog 8-Br-cAMP renders the cells more glucose competent. Basal levels of cAMP are elevated in RIN 1046-38 cells, which overexpress the GLP-1 receptor (MontroseRafizadeh et al., 1997) relative to the parental cells (18.6 vs. $35.96 \mathrm{nmol} \mathrm{dm}^{-3} / \mathrm{mg}$ protein hour, parental vs. transfected). This is reflected by increased insulin secretion both in the absence of glucose ( $1.62 \mathrm{vs.} 2.66 \mathrm{pmol} \mathrm{dm}^{-3} / \mathrm{mgprotein}$ hour; parental $v s$. transfected) and in response to $0.5 \mathrm{mM}$ glucose $(2.21$ vs. $4.52 \mathrm{pmol}$ /mgprotein hour; parental $v s$. transfected). Cells overexpressing the receptor respond to GLP-1 even in the absence of glucose, indicating that an increased cAMP level is permissive to the glucose response (Montrose-Rafizadeh et al., 1997).

Treatment of RIN 1046-38 cells with GLP-1 (10 nM) increases tyrosine phosphorylation of proteins (Zhou and Egan, 1997), specifically, phosphorylation of the SNARE (soluble NSF attachment protein receptor) protein, SNAP-25 (Figure 2A). SNARE proteins are requircd for the docking and fusion of vesicles with their target membrane in a variety of organisms and tissues (Jahn and Södhof, 1999). Cleavage of SNAP-25 results in an inhibition of $\mathrm{Ca}^{2+}$-stimulated insulin release in $\beta$-cell lines and primary rat islets (Sadoul et al., 1995). Tyrosine phosphorylation of SNAP-25 and, correspondingly, GLP-1-induced insulin secretion are attenuated by the tyrosine kinase inhibitor genistein and enhanced by vanadate, a tyrosine phosphatase inhibitor. Thus, activation of SNAP-25 is probably another aspect of the mechanism by which GLP-1 stimulates exocytosis and consequently the amount of insulin secreted by the $\beta$-cell.

\section{B. INCREASE IN THE NUMBER OF CELLS SECRETING INSULIN}

Virtually all RIN cells secreted insulin when glucose $(20 \mathrm{nM})$ and membrane depolarization were applied simultaneously (Table I, compare conditions 5 and 6). GLP-1 sensitizes more cells for secretion in the presence of glucose or membrane depolarization but not in the absence of glucose (Montrose-Rafizadeh et al., 1994). Thus, GLP-1 renders more cells glucose competent (Holz et al., 1993) and recruits more cells into a secretory mode. This can be understood in terms of the action of GLP-1 on the $\mathrm{K}_{\mathrm{ATP}}$ channels. The greater membrane depolarization increases the number of these channels that are closed and, consequently, the $\mathrm{Ca}^{2+}$ 
A
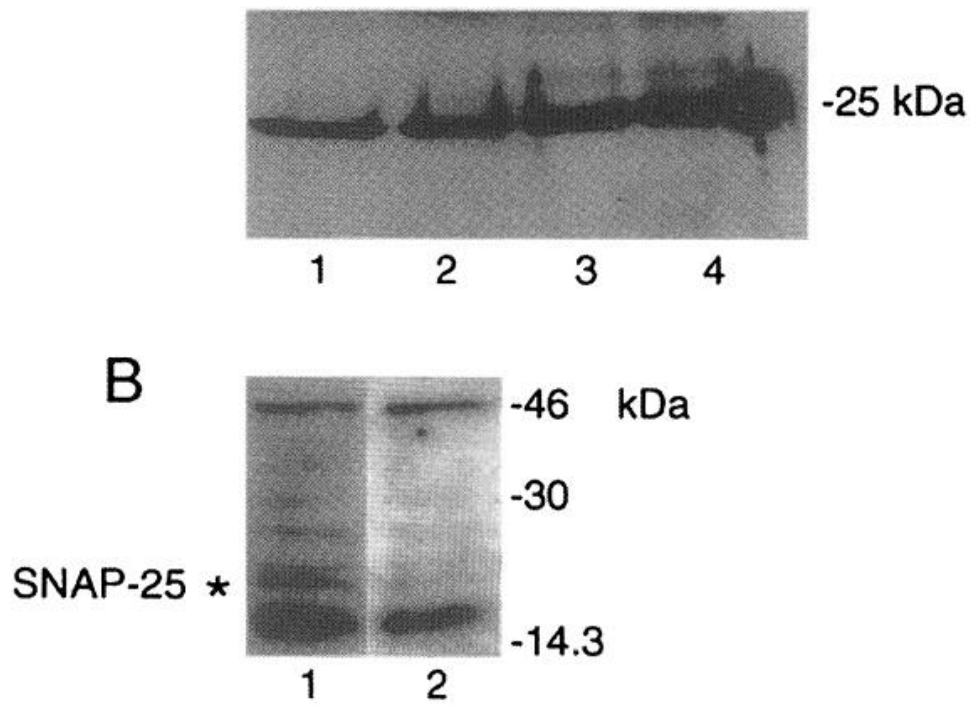

FIG. 2. Western blot illustrating the effects of the insulin secretagogues, GLP-1 and glucose, on tyrosine phosphorylation of SNAP-25. (A) RIN 1046-38 cells treated as follows: 1) no treatment, 2) glucose $(20 \mathrm{mM}), 3) \mathrm{GLP}-1(20 \mathrm{nM})$, and 4) glucose $(20 \mathrm{mM})$ and GLP-1 $(20 \mathrm{nM})$. Cells were lysed and the phosphoproteins immunoprecipitated using a monoclonal antiphosphotyrosine antibody. The immunoprecitates were separated by SDS-PAGE and proteins transferred to polyvinylidene difluoride (PVDF) membrane, which was incubated with a monoclonal anti-SNAP-25 antibody. (B) Western blot of immunoprecipitates from cells treated with glucose and GLP-1 and probed for an antiphosphotyrosine anitbody in absence 1) or presence 2) of a 1000-fold excess of phosphorylated tyrosine. [Adapted from Zhou J., and Egan J.M. Biochem. Biophys. Res. Commun. 238, 297-300, 1997. Copyright Academic Press, Inc.]

current undergoes more-extensive inactivation before the cells start repolarizing (Gromada et al., 1998). The interburst membrane potential does not fall back to resting membrane potential, so the cells can begin depolarizing even before they completely recover from inactivation. Therefore, the silent interburst intervals are shorter and the periods for which the $\mathrm{Ca}^{2+}$ channels are active are longer (Gromada et al., 1998).

\section{GLP-1 ACUTE EFFECTS ON INSULIN SECRETION IN VIVO}

Aging is an etiological factor in non-insulin-dependent diabetes. While impaired insulin secretion, reduced insulin sensitivity, and obesity are the predisposing factors for this disease, a general decline in $\beta$-cell function with age is noted 
even in lean subjects (United Kingdom Prospective Diabetes Study, 1995). The Wistar rat is an ideal model for studying the effects of aging on the progression of diabetes, as these rats develop glucose intolerance and have a significantly lower insulin response to a glucose load with aging (Reaven et al., 1979). As in the insulinoma cell line, individual pancreatic $\beta$-cells harvested from young (3month) and old (22-month) Wistar rats display an improved response to glucose across a range of glucose concentrations, when co-incubated with GLP-1, as illustrated by the data in Table II. In the absence of GLP-1, the number of cells secreting insulin is significantly reduced in the population of cells from old animals. The addition of GLP-1 redeems the glucose responsiveness of the older cells. Hence, the number of cells secreting insulin are on a par with the values observed in the younger animals.

The capacity of GLP-1 to render $\beta$-cells glucose competent is dramatically illustrated by the improved glucose tolerance in old Wistar rats that have been subjected to an intravenous glucose tolerance test (IVGTT) following a bolus of GLP-1 (De Ore et al., 1997). Old (22-month) animals have a delayed and attenuated acute insulin response during an IVGTT, when compared to 3-month-old rats (Figure 3). Of the range of GLP-1 concentrations tested (i.e., 0.05, 0.1, 0.2, 0.4, and $0.5 \mathrm{nmol} \mathrm{kg}$ ), the maximum response in both young and old animals was attained with a $0.4 \mathrm{nmol} \mathrm{kg}^{-1}$ bolus of GLP-1. Serum insulin levels peaked at 2 minutes in the young animals $(859 \mathrm{pmol} / \mathrm{l})$. The old animals did not reach peak insulin levels until 7 minutes after completion of the intravenous glucose administration and were deficient when compared to the younger ones $(656 \mathrm{pmol} / \mathrm{l})$.

TABLE II

Percentage of Plaque-forming $\beta$-Cells Isolated from Young (3-Month) and Old (22-Month) Wistar Rats in Response to Varying Concentrations of Glucose and with GLP-I

Glucose (mM)

\begin{tabular}{llccc} 
& \multicolumn{4}{c}{ Glucose (mM) } \\
\cline { 2 - 5 } Rat & 3.5 & 5 & 11 & 20 \\
\hline Young (3 month) & $7 \pm 1$ & $10 \pm 1$ & $17 \pm 1$ & $17 \pm 2$ \\
Old (22 month) & $2 \pm 1$ & $7 \pm 1$ & $11 \pm 2$ & $10 \pm 2$ \\
Old + GLP-1 (10 nm) & $6 \pm 1$ & $11 \pm 4$ & $15 \pm 5$ & $15 \pm 7$ \\
\hline
\end{tabular}

Islets were extracted as described previously (Egan et al., 1991) and dissociated into individual $\beta$-cells that were then incubated for 1 hour in the absence of glucose (Montrose-Rafizadeh et al,, 1994). The cells were then challenged with varying concentrations of glucose, as shown, for a period of 10 minutes. $\beta$-cells originating from old islets were also treated with GLP-1 concomitantly with glucose to assess the impact of this treatment on the number of cells secreting insulin. 

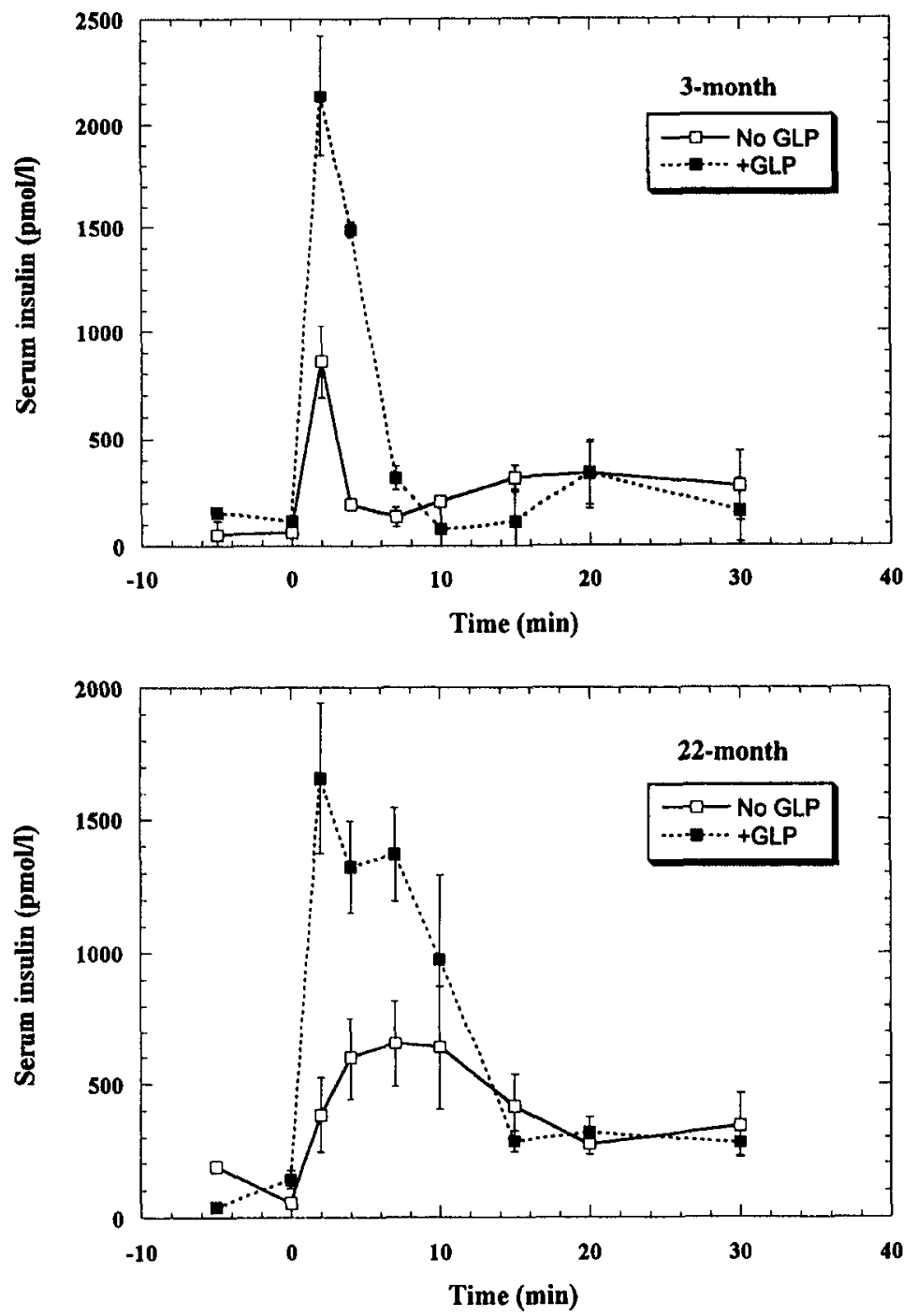

FIG. 3. Insulin levels in young (top panel) and old (bottom panel) rats after an IVGTT $(0.5 \mathrm{~g} / \mathrm{kg}$ glucose $)$ in the presence or absence of a bolus of GLP-1 $(0.4 \mathrm{nmol} / \mathrm{kg})$. Each timepoint represents the mean \pm S.E.M. of six animals. Blood was drawn at the times plotted on the graph. In young rats (top panel), $\mathrm{AUC}_{0-20}$ was $2504 \pm 251$ for IVGTT alone vs. $8180 \pm 1043 \mathrm{pmol} / \mathrm{l}$ for IVGTT with $0.4 \mathrm{nmol} / \mathrm{kg}$ GLP-1; $p=0.006$ by one-way ANOVA. In old rats (bottom panel), $\mathrm{AUC}_{0-15}$ was $7973 \pm 2096$ for IVGTT alone vs. $16,160 \pm 3232 \mathrm{pmol} / \mathrm{l}$ for IVGTT with $0.4 \mathrm{nmol} / \mathrm{kg} \mathrm{GLP-1} ; p=0.012$ by one-way ANOVA. [Reprinted with permission from De Ore K., Greig N.H., Holloway H.W., Wang Y., Perfetti R., and Egan J.M...J. Gerontol. Biol. Sci. 52A, B245-B249, 1997. Copyright The Gerontological Society of America.] 
When GLP-1 $(0.4 \mathrm{nmol} / \mathrm{kg})$ was administered prior to the IVGTT, the amount of insulin secreted by the old animals increased two-fold relative to that seen in the absence of GLP-1. First-phase insulin response to glucose was restored, as demonstrated by the higher blood insulin levels at 2 minutes in those treated with GLP-1 vs. the controls $(1,659$ vs. $384 \mathrm{pmol} / \mathrm{l}, p=0.002)$ and the significantly increased $\mathrm{AUC}_{0-15}$ for insulin (16,160 vs. $\left.7973 \mathrm{pmol} / \mathrm{l}, p=0.012\right)$.

Thus, the ability to respond to the insulinotropic influence of GLP-1 is retained even in old, glucose-intolerant rats. The magnitude of the response is the same regardless of age and there is a reversal of the age-related decline in $\beta$-cell function. This is compatible with the in vitro observations and can be explained by the ability of GLP-1 to sensitize previously unresponsive $\beta$-cells to glucose and to increase the amount of insulin secreted per cell.

\section{GLP-1 Administered Chronically: Effects on Insulin Secretion}

This parity of response between young and old animals is exhibited following a 48-hour infusion of GLP-1 (Wang et al., 1997). Administration of GLP-1 (1.5 pmol kg-1 $\mathrm{min}^{-1}$ ) by means of an Alzet micro-osmotic pump implanted in the intracapular region dramatically improved the response of both 3- and 22-monthold Wistar rats to an intraperitoneal glucose tolerance test (IPGTT), performed 120 minutes after removal of the pumps (Figures 4 and 5).

As in the acute study, the striking feature of the IPGTT is the reversal of the glucose intolerance in the old animals. The rise in blood glucose levels was identical to that in the young treated animals and significantly lower than the saline-treated controls (Figure 4). The insulin response peaked at 15 minutes in the treated animals vs. a peak insulin response at 30 minutes for the controls (Figure 5). This accounts for the lower blood glucose levels at 15 minutes in the treated animals. Intra-islet insulin content following acid ethanol extraction was, on average, three-fold greater in the treated old animals than in the control old animals (5.31 vs. $19.68 \mathrm{ng}$ of insulin per $\mu \mathrm{g}$ of total pancreatic protein).

The in vivo results correspond with observations in vitro (Wang et al., 1995) when RIN 1046-38 insulinoma cells were incubated for 24 hours with GLP-1 (10 $\mathrm{nM}$ ). During this extended exposure to GLP-1, there was a 3.5 -fold increase in the cumulative amount of insulin secreted in the 24-hour incubation period and a 1.5-fold increase in intracellular insulin content, relative to untreated controls. Following this incubation, cells were washed extensively to remove GLP-1 and glucose, incubated in a glucose-free buffer for a period of 1 hour, then subjected to a 1-hour insulin-release experiment in response to varying concentrations of glucose. Glucose responsiveness was significantly improved in the cells preincubated with GLP-1: at $10 \mathrm{mM}$ glucose, the untreated cells increased insulin secretion by 1.9 -fold, compared with $0 \mathrm{mM}$ glucose, whereas the GLP-1 preincubated 

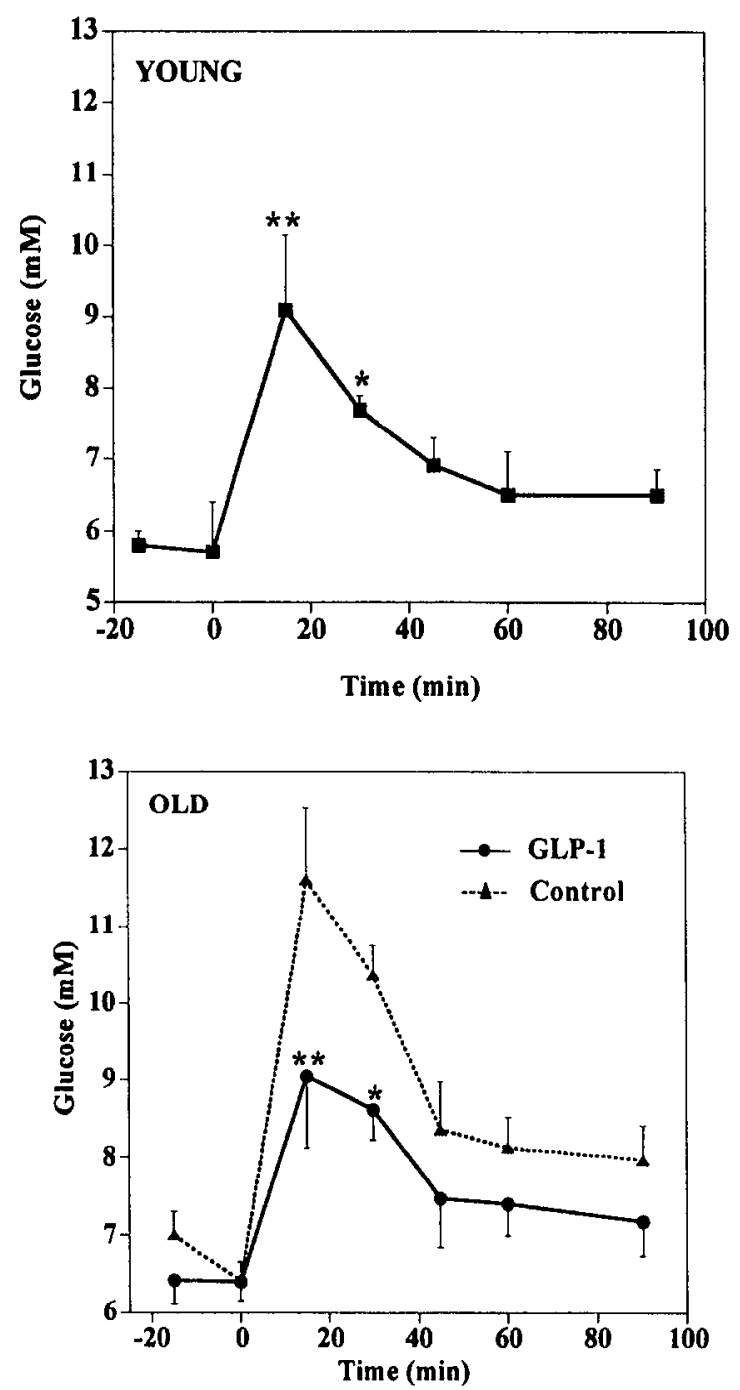

FIG. 4. Plasma glucose levels during an IPGTT $(1 \mathrm{~g} / \mathrm{kg})$ in young (3-month) (top panel) and old (22-month) rats (bottom panel). GLP-1-treated old animals received $1.5 \mathrm{pmol} \mathrm{kg}^{-1} \mathrm{~min}^{-1}$ for 48 hours by subcutaneous infusion. All other animals were infused for 48 hours with saline. The results are shown as mean \pm S.E.M. of six animals in each group. Repeated measures analysis of variance from 0 to 30 minutes showed a value of $P<0.05$ for the GLP-1-treated vs. control old animals. ${ }^{*} P<0.05$, ${ }^{* *} \mathrm{P}<0.01$, as determined by unpaired Student's $t$ test for control young vs. control old animals and or GLP-1-treated vs. control old animals. [Reprinted with permission from Wang, Y., Perfetti, R., Greig, N.H., Holloway, H.W., DeOre, K., Montrose-Rafizadeh, C., Elahi, D., and Egan, J.M. J. Clin. Invest. 99, 2883-2889, 1997. Copyright Rockefeller University Press.] 


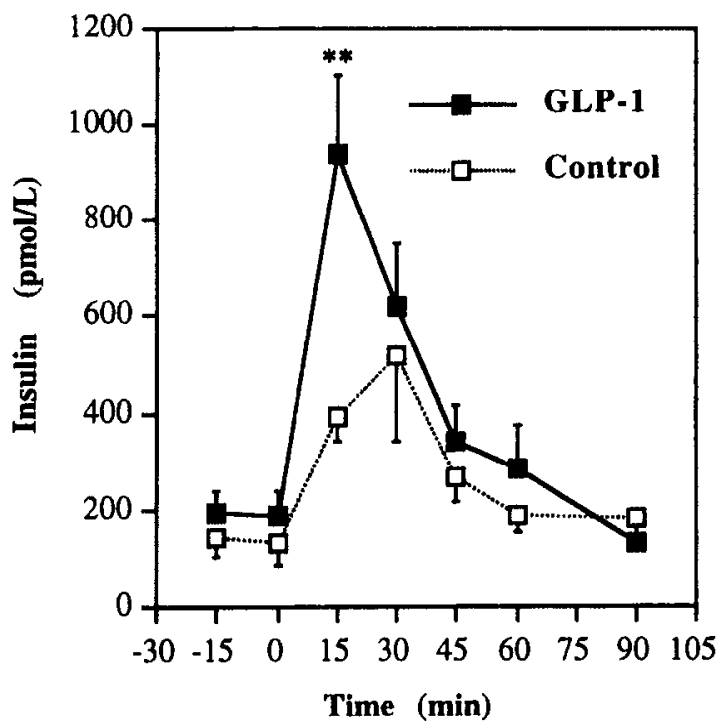

FIG 5. Plasma insulin levels during an intraperitoneal glucose $(1 \mathrm{~g} / \mathrm{kg})$ tolerance test in 22 month-old animals. GLP-1-treated animals received $1.5 \mathrm{pmol} / \mathrm{kg}^{-1} \mathrm{~min}^{-1}$ for 48 hours by subcutaneous infusion. Controls were infused with saline. The results are mean \pm S.E.M. of six treated and six control animals. Repeated measures analysis of variance from 0 to 30 minutes showed a value of *P $<0.05,{ }^{* *} P<0.01$, as determined by unpaired Student's $t$ test. [Reprinted with permission from Wang, Y., Perfetti, R., Greig, N.H., Holloway, H.W., DeOre, K., Montrose-Rafizadeh, C., Elahi, D., and Egan, J.M. J. Clin. Invest. 99, 2883-2889, 1997. Copyright Rockefeller University Press.]

cells increased insulin secretion by 2.8 -fold. This indicates that the preincubation period with GLP-1 had potentiated the glucose sensitivity of the cells.

The time lapse between termination of treatment and the ongoing effect of GLP-1 observed in vitro and in vivo indicate that the effect of the peptide extends beyond an impact on insulin release. This is of particular importance, given the short half-life (6-8 minutes) in vivo of the peptide (Elahi et al., 1994). Therefore, we examined the effects of GLP-1 on the mRNA levels of insulin and the glucose-sensing components of the $\beta$-cell in the islets of the treated rats, specifically, the high $\mathrm{K}_{\mathrm{m}}$ glucose transporter GLUT2 and the high $\mathrm{K}_{\mathrm{m}}$ glucose phosphorylating enzyme, glucokinase (GCK).

\section{GLP-1 Administered Chronically: Effects on $\beta$-cell Gene Expression}

The mRNA levels of insulin and GLUT2 measured in total RNA extracted from mice pancreata decrease progressively with age (Perfetti et al., 1995,1996). 
In contrast, GCK levels increase significantly with age, which we interpret as a compensation within the glucostat for the diminishing levels of GLUT2. A similar age-related pattern in mRNA levels was observed in the untreated animals (Wang et al., 1997) in the 48-hour study on the Wistar rats. Levels of insulin mRNA were decreased by 50 percent, GLUT2 mRNA levels by 70 percent, with no change observed in GKC mRNA levels in old (22-month) relative to young (3-month) animals (Figure 6). Not only did GLP-1 elevate the levels of all three of these mRNAs in the young animals but it also completely reversed the decrease observed in GLUT2 and insulin mRNA levels in the old animals. When GLP-1 infusion was accompanied by an infusion of a competitive antagonist, exendin (9-39), no enhancement of the mRNA expression of these genes was observed. Treatment with the antagonist alone decreases mRNA levels, indicating an inhibition of endogenous GLP-1 effects. Significantly, this was the first reported observation of a pharmacologically induced elevation of GLUT2 mRNA. Sulfonylurea agents, for example, increase insulin secretion by inhibition of the $\mathrm{K}_{\mathrm{ATP}}$ channels. A recent report (Porzio et al., 1999) shows that glimepiride, a sulfonylurea derivative, upregulates GLUT2 and GKC mRNA following a 24-hour treatment of the insulinoma cells $\beta$ TC6-F7. However, at the 48- and 72-hour timepoints, GLUT2 and GKC mRNA and protein levels were reduced relative to basal levels, indicating a downregulation of these genes by the drug.

\section{GLP-1 Upregulates PDX-1 in Vitro and in Vivo}

One method of influencing transcriptional regulation of the insulin gene is directly mediated by the cAMP-response element-binding protein (CREB). However, this is not the case for GLUT2, as it does not possess a CREB-binding site. Therefore, in the GLP-1 upregulation of these genes, a master regulatory transcription factor may be downstream of CREB that is responsible for the regulation of all three genes; GLUT2, insulin, and GKC. The most-probable candidate is the homeodomain transcription factor PDX-1, which is known to regulate insulin (Petersen et al., 1994), GLUT2 (Waeber et al., 1996), GKC, and islet amyloid precursor genes (Watada et al., 1996a,1996b). PDX-1 is essential for the early development of the pancreas (Jonsson et al., 1994) and the maintenance of the $\beta$-cell phenotype (Ahlgren et al., 1998). Under conditions of sustained hyperglycemia, such as in the diabetic state, there is a downregulation of PDX-1 expression and a decrease in insulin secretion (Olson et al., 1995). PDX-1 expression, as measured by immunofluorescence staining of sections taken from islets extracted from the Wistar rats of various ages, decreases by approximately 50 percent in animals older than 13 months. Therefore, one might expect this downregulation would lead to a downregulation of the genes under the transcriptional control of 


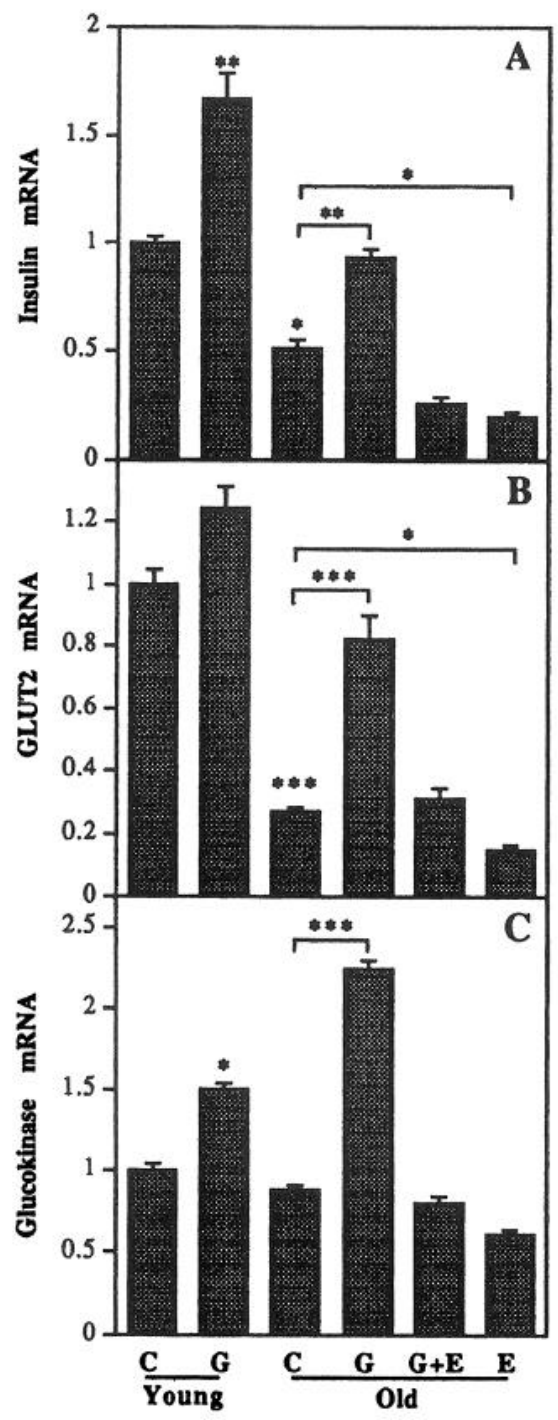

FIG. 6. Effects of normal saline (C), GLP-1 (G), GLP-1 and exendin (9-39) (G and E), and exendin (9-39) (E) treatment for 48 hours on mRNA levels of insulin (panel A), GLUT2 (panel B), and glucokinase (panel C) using pancreatic poly-A RNA in young and old animals. Images of cDNA hybridization were quantified using densitometry and normalized with those of poly-A. Data are shown as mean \pm S.E.M. $\left(n=6\right.$ animals per group), with control data assigned a value of $1 .{ }^{* P}<0.05,{ }^{* *} \mathrm{P}$ $<0.01,{ }^{* * *} \mathrm{P}<0.001$ by unpaired Student's $t$ test. [Reprinted with permission from Wang, Y., Perfetti, R., Greig, N.H., Holloway, H.W., DeOre, K., Montrose-Rafizadeh, C., Elahi, D., and Egan, J.M.. J. Clin. Invest.. 99, 2883-2889, 1997. Copyright Rockefeller University Press.] 
PDX-1 and that GLP-1 treatment should lead to an upregulation of PDX-1 expression.

Returning to the insulinoma cell line RIN 1046-38 (Wang et al., 1999), we have demonstrated a functionally significant upregulation of the PDX-1 gene in response to GLP-1 (10 nM). Following 1 hour of treatment, PDX-1 mRNA levels increased 1.3-fold (Figure 7) above basal levels $(p<0.01$ ), with a maximum 1.4 -fold increase at 2 hours $(p<0.01)$. This coincides with a rise in insulin mRNA expression that reaches a maximum level at 3 hours. For the entire duration of the 12-hour treatment, levels of PDX-1 mRNA and protein remained significantly above basal. PDX-1 protein levels were 1.6-fold above basal in nuclear and whole-cell extracts $(p<0.001)$. Treating the cells with glucose $(6$ and $15 \mathrm{mM})$ alone resulted in translocation of, but not transcription or translation of, $p d x-1$. This, at least in part, explains the ability of GLP-1 to stimulate insulin biosynthesis and provides a mechanism for the long-term effects of GLP-1 on $\beta$-cell insulin content and insulin secretion. The functional significance of the GLP-1-induced PDX-1 expression was demonstrated by the increase in binding of PDX-1 to the A1 element of the insulin promoter (Macfarlane et al., 1994) consequent upon GLP-1 treatment (Figure 8). Maximum binding occurs at the 2-hour timepoint. The specificity of this binding was confirmed by supershift analysis and competitive binding studies. These results have been substantiated in a recent report by Buteau and colleagues (1999) demonstrating a similar upregulation of PDX-1 by GLP-1 in the insulinoma cell line INS-1.

This led us to believe that restoration of $\beta$-cell function in the glucose-intolerant Wistar rats upon treatment with GLP-1 is mediated by the transcription factor activator PDX-1 and prompted us to examine PDX-1 protein and mRNA content in whole pancreata and islets extracted from Wistar rats treated with GLP-1 (Perfetti et al., 2000). The trend in the level of expression of PDX-1 paralelled that of the insulin and GLUT2 genes (i.e., a decrease in expression with age but an increase of comparable magnitude observed in both young (6-month) and old (22-month) pancreata upon treatment with GLP-1). GLP-1 treatment (1.5 pmol kg-1 $\mathrm{min}^{-1} ; 48$-hour infusion using a micro-osmotic pump) upregulated $p d x-1$ mRNA in both the islets and in whole pancreatic extracts. The amount of $p d x$ ImRNA in the whole pancreas was twice that seen in the untreated pancreas, which is an interesting phenomenon, given that the islets comprise only about 0.5 to 1 percent of the total pancreatic mass. PDX-1 protein levels also were increased in response to treatment in islets and whole pancreas. This fits with what we see in mice that have been treated with continuous subcutaneous GLP- 1 infusion for 14 days. Western blot analysis reveals a 4.6-fold increase in PDX-1 levels in total pancreata (Stoffers et al., 2000).

Following 2 days of treatment, the extent of proliferative activity in the pancreata of the treated rats (both young and old) incrcased, as determined quali- 


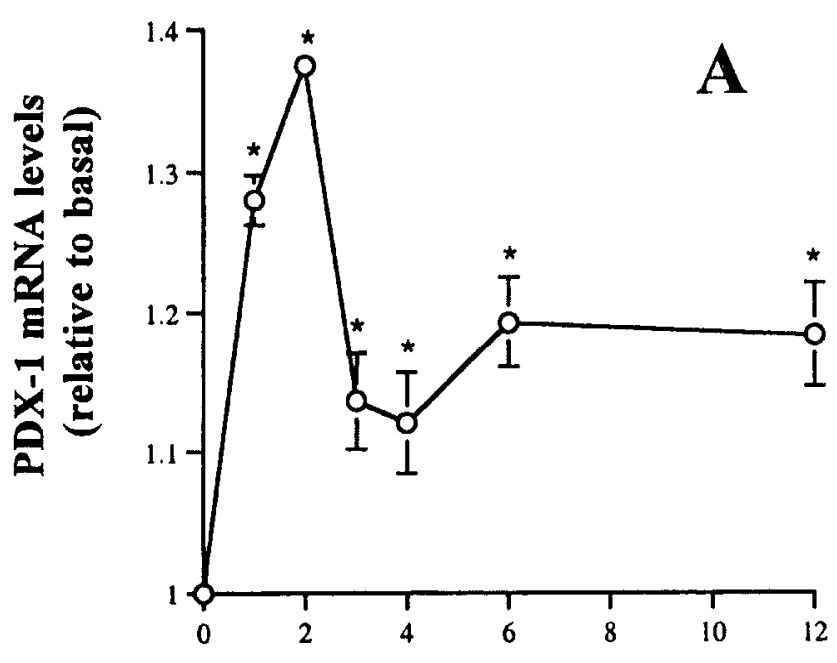

Time (h)

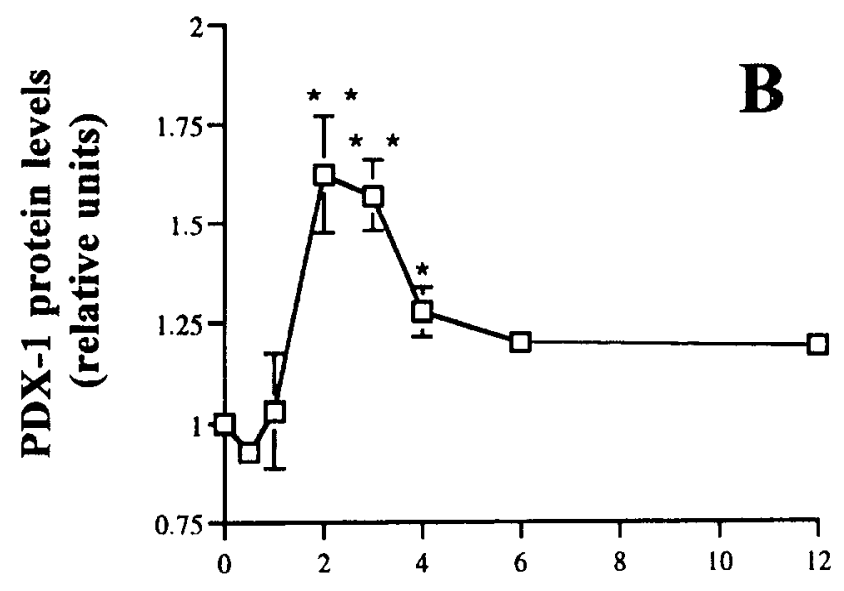

Time (h)

FIG. 7. Timecourse of the effect of GLP-1 (10 nM) on PDX-1 mRNA (panel A) and protein levels (panel B) in RIN 1046-38 cells. Nuclear extracts were used for the Western blot. [Adapted with permission from Wang, X., Cahill, C.M., Pineyro, M.A., Zhou, J., Doyle, M.E., and Egan, J.M. Endocrinology 140, 4904-4907, 1999. Copyright The Endocrine Society.] 

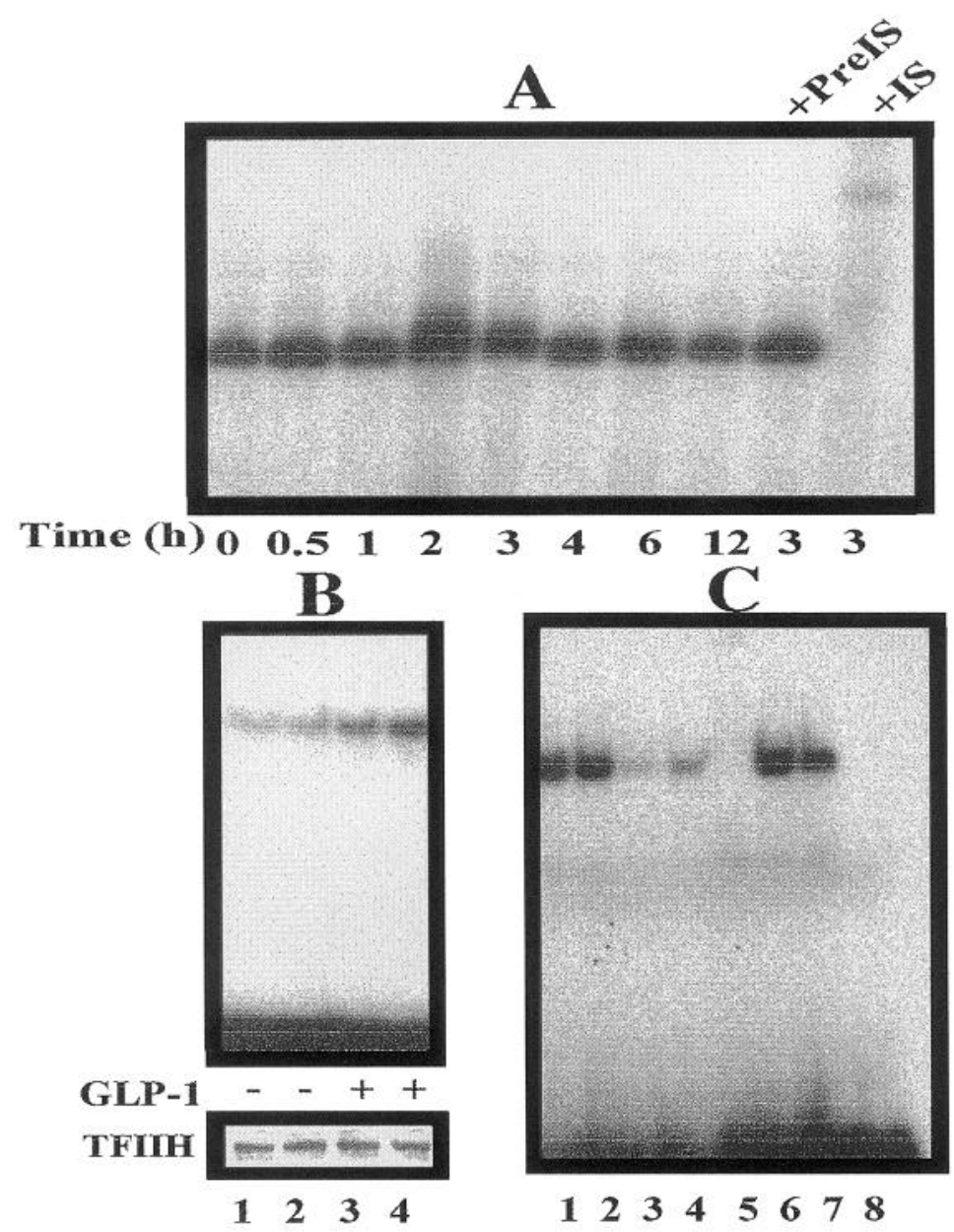

FIG. 8. Timecourse and effect of GLP-1 on PDX-1 protein binding to the rat insulin promoter A1 element using nuclear extract from RIN cells that had been treated \pm GLP-1 (10 nM). (A) Cells were cultured in glucose $(6 \mathrm{mM})$ and GLP-1 for the indicated times. Equal concentrations of the proteins were analyzed by electrophoretic mobility shift assays (EMSA) for binding to Al element of rat insulin II promoter ${ }^{32} \mathrm{P}$-labeled probe. The last lane indicates a shift in the binding with PDX-1 antibody (IS). (B) EMSA of protein from cells treated \pm GLP-1 for 2 hours. Western blot analysis of transcription factor IIH (TFIIH) was used as a control of protein levels loaded onto the gel in EMSA. (C) Competition and supershift analysis of A1 binding complex. Lanes 1 and 2; addition of unlabeled HSE promoter $(10 \times, 5 \times)$ : Lanes 3 and 4; addition of unlabeled $A 1$ element $(10 \times, 5 \times)$ : Lane 5 ; addition of the PDX-1 antibody, causing a shift in the binding: Lane 6; addition of PDX-1 preimmune serum: Lane 7; nuclear extract and labeled A1 element: Lane 8; Al element alone. [Reprinted with permission from Wang X., Cahill C.M., Pineyro M.A., Zhou J, Doyle M.E., and Egan J.M. Endocrinology 140, 4904-4907, 1999. Copyright The Endocrine Society.] 
tatively by proliferative cell nuclear antigen (PCNA) staining. The contrast between the treated and untreated pancreata was very distinct. There was extensive PCNA staining in acinar tissue as well as in ducts in the treated pancreata, with very little positive staining seen in these areas of the untreated pancreata. This proliferative response had dissipated following 5 days of treatment with GLP-1; at this timepoint, there was no difference between the treated and control tissues. There was a substantial increase in the $\beta$-cell mass of the treated pancreata $(7.02$ vs. $4.88 \mathrm{mg}$ : treated vs. control, respectively, $p=0.02$, after 5 days of treatment). This was reflected by the distribution of insulin staining in the pancreata that had been exposed to GLP-1 treatment. In the saline-treated animals, discrete islets can be seen with no insulin staining elsewhere. In contrast, sections from GLP-1 animals exhibit insulin staining in small clusters and ducts as well as in the mature islets. These insulin-positive clusters were obvious by 5 days. A few insulin-positive cells could be seen in ducts as early as 3 days. Clearly, the induction of proliferation by GLP-1 is followed by differentiation of some of these cells into small clusters of $\beta$ cells.

The increase in gene expression of the key $\beta$-cell regulatory factor $p d x-1$ in the acinar and ductular tissue, and the subsequent increase in $\beta$-cell mass, all point to GLP-1 being an endocrinotrophic factor. This property of GLP-1 also is shared with exendin- 4 and has been further explored in mice and in an in vitro acinar cell model (see section VII).

\section{The Long-acting GLP-1 Agonist, Exendin-4}

As mentioned briefly earlier, the half-life of GLP-1 in vivo is very short, necessitating either continuous infusion or frequent subcutaneous injection, making the administration of this medicine as cumbersome as the daily treatment of type 1 diabetic subjects with insulin. Consequently, for a type 2 diabetic subject, the potential benefits of GLP-1, not withstanding $\beta$-cell regeneration, are oulweighed by the disadvantages of the treatment regimen. Means of circumventing this inconvenience are currently under investigation in several laboratories but one therapy appears to offer all of the physiological and pharmacological benefits of GLP-1 without the disadvantage of a short biological half-life.

In 1993, the capacity of exendin-4 as an agonist at the GLP-1 receptor was first reported (Goke et al., 1993; Thorens et al., 1993). Exendin-4 is a 39-amino acid peptide with a 53 percent amino acid homology with GLP-1 (Eng et al., 1992) found in salivary glands of the Gila monster lizard (Heloderma suspectum). Attempts to find the mammalian homolog of this gene have failed so far (Chen and Drucker, 1997; Pohl and Wank, 1998). Despite the nonmammalian nature of this protein and its implied potential antigenicity, we have demonstrated it to be a very-potent insulin secretagogue in rodents and humans, possessing all of the 
pharmacological and physiological properties of GLP-1 with two vital exceptions, its duration of action in vivo and potency.

Exendin- 4 , when administered acutely $(0.4 \mathrm{nmol} / \mathrm{kg})$, increases insulin secretion in the Wistar rats more than two-fold above the levels obtained with GLP-1 at the same concentration (Greig et al., 1999). The $\mathrm{ED}_{50}$ values were found to be 0.0143 and $0.19 \mathrm{nmol} / \mathrm{kg}$ for exendin- 4 and GLP-1, respectively. Thus, exendin- 4 is 10 times more potent than GLP-1 in vivo. The increased insulin secretion arises from the higher intracellular cAMP concentrations generated by exendin- 4 , as comparcd to GLP-1. In islets isolated from the Wistar rats, a dose of $1 \mathrm{nmol}$ of exendin- 4 produced a three-fold greater cAMP response relative to an equivalent concentration of GLP-1.

Long-term treatment with exendin-4 significantly improved glucose tolerance and hemoglobin Alc $\left(\mathrm{HbA}_{l \mathrm{c}}\right)$ levels in $d b / d b$ mice (Grieg et al., 1999). Following 13 weeks of once-daily intraperitoneal exendin- $4(24 \mathrm{nmol} / \mathrm{kg})$ injections, the treated mice had a lower mean $\mathrm{HbA}_{\mathrm{Ic}}$ than did the saline-injected controls ( $4.7 \mathrm{vs.}$ 8.8 percent). The response to an IPGTT was significantly improved, as insulin concentrations were higher ( 4600 vs. $707.2 \mathrm{pmol} / \mathrm{l}$ ) in exendin-4 treated mice, compared with saline-treated controls. Young and coworkers have extended the observations on the antidiabetic properties of exendin- 4 in animal models to include Zucker diabetic fatty (ZDF) rats and diabetic rhesus monkeys (Young et al., 1999).

Using the Zucker fatty (ZF) rat as a model, we have shown that twice-daily injections of exendin-4 led to a deceleration in weight gain and fat deposition as well as amelioration of diabetic symptoms (Szayna et al., 2000). The ZF rat is a good model for obesity, as it has a defect in the leptin receptor (Lepr) due to a Gln269Pro mutation (Chua et al., 1996). Therefore, plasma leptin levels are elevated but the rat is unresponsive to the satiety effect of this protein. As a consequence, it overeats, gains weight quickly, and becomes obese and diabetic. These rats, when treated with exendin- $4(10 \mu \mathrm{g} / \mathrm{kg})$ via a daily intraperitoneal injection, showed an initial drop (for the first 5 days) in food intake and weight. Subsequently, however, these parameters were indistinguishable from those of the saline-treated controls. Following 2 weeks of this treatment, a second daily injection was added to the protocol. This resulted in a sustained reduction in food intake and weight gain relative to controls for the remainder of the 56-day treatment regimen. Using magnetic resonance imaging (MRI), it was possible to image the areas of adipose tissue in the rats and hence monitor the rate at which fat was laid down in the abdomen. At the completion of the study (56 days), the amount of fat in both the visceral and subcutaneous compartments of the treated animals was significantly less than in the controls. Thus, despite the high leptin levels, food intake could be influenced by exendin- 4 treatment. Should this chronic effect be 
transferable to humans, it would be beneficial in the management of type 2 diabetes.

As the data from our rodent experiments showed the potential of exendin- 4 as a treatment for type $2 \mathrm{DM}$, we proceeded with acute experiments with exendin4 in nondiabetic and type 2 diabetic subjects (Egan et al., 1999). We demonstrated in both groups of volunteers that exendin-4 is a potent insulinotropic agent. Plasma insulin levels achieved in response to intravenous infusion of $0.15 \mathrm{pmol}$ $\mathrm{kg}^{-1} \mathrm{~min}^{-1}$ for 1 hour were comparable to those achieved with $1.5 \mathrm{pmol} \mathrm{kg}{ }^{-1} \mathrm{~min}^{-1}$ of GLP-1. Additionally, the duration of its biological effects far exceeded those of GLP-1. Insulin levels did not even begin to decrease for at least 3 hours following termination of exendin-4 infusion, unlike GLP-1 infusion, where insulin levels begin to decrease within minutes of termination. Indeed, 6.5 hours after completion of the exendin-4 infusion, plasma insulin levels were still double the fasting values, even in subjects with type 2 diabetes.

The nondiabetic subjects, but not the diabetic subjects, required intravenous glucose for up to 8 hours after termination of exendin- 4 to prevent blood glucose from dropping below $80 \mathrm{mg} / \mathrm{dl}$. This was despite having eaten a meal containing 550 calories 3.5 hours after termination, which, again, points to its sustained biological effect. There was no rise in postprandial levels of plasma insulin relative to those measured just prior to eating. However, as stated earlier, the fasting levels in both nondiabetic and diabetic subjects were twice basal values for several hours following treatment. As there was no postprandial rise in blood glucose after eating, our assessment is that the food was not being utilized. We also measured GLP-1 levels and could not demonstrate any rise after eating, which indicates that food was probably not leaving the stomach. It is therefore evident that exendin-4 prevents postprandial rise in blood glucose, most probably via inhibition of gastric emptying.

Changes seen in other metabolic parameters are consistent with increased insulin secretion in response to exendin-4. Glucagon and nonesterified fatty acid levels decreased as insulin levels increased. As exendin- 4 increases endogenous insulin secretion, one would expect that intra-islet levels of insulin, though not quantifiable, would be far greater than plasma levels. Yet, glucagon levels in diabetic subjects did not suppress to levels seen in nondiabetic subjects. A comparison of the magnitude of suppression, as opposed to absolute levels, indicates that glucagon levels were approximately half the fasting levels in both nondiabetic and diabetic subjects in the 3 hours following exendin- 4 treatment. Therefore, the suppression observed as a result of exendin- 4 is the insulin-dependent component of glucagon regulation. This also indicates that there is an insulin-independent component to glucagon regulation that is altered in type 2 diabetes and is not influenced by endogenous insulin secretion. We conclude that exendin-4 is a 
powerful insulinotropic agent in humans. Its effects on the $\beta$-cells of the pancreas appear long-lived, when compared to GLP-1.

It is feasible that exendin- 4 could be administered in an oral formulation. The stability of the compound in vivo can be attributed to the absence of a dipeptidyl peptidase IV cleavage site in N-terminal sequence (Mentlein, 1999) and to a reduced susceptibility to cleavage by neutral endodpeptidase 24.11 (Hupe-Sodmann et al., 1995) at sites throughout the GLP-1 sequence that are not found in exendin-4. We are currently investigating chimeric derivatives to assess the importance of these sites and to examine which ones confer the greater potency to exendin-4.

\section{Endocrinotrophic Properties of GLP-1 and Exendin-4}

Expansion and subsequent differentiation of the ductal epithelium into clusters of $\beta$-cells has been postulated as the route to $\beta$-cell neogenesis in adult life (Bonner-Weir et al., 1993; Gu et al., 1994). PDX-1 expression, as quantified by immunofluorescence and western blot, is upregulated in the ductular tissue of pancreatectomized rats (Sharma et al., 1999). This upregulation follows a burst of proliferation (Sharma et al., 1999). Thus, PDX-1 is an integral transcription factor in the process of $\beta$-cell neogenesis. We also observe a burst of proliferation in GLP-1-treated animals and upregulation of PDX-1 by western blot of whole pancreas. Using immunofluorescence, enhanced expression of PDX-1 was observed in the ducts and the exocrine tissue of both nondiabetic and diabetic $d b / d b$ mice treated with exendin-4 for 2 weeks (Stoffers et al., 2000). Furthermore, Xu and colleagues have shown $\beta$-cell neogenesis in response to exendin- 4 treatment ( $1 \mathrm{nmol} / \mathrm{kg}, 10$ days), wherein $\beta$-cell mass was increased by 40 percent (Xu et al., 1999). Collating these data allows us to surmise that GLP-1 and exendin-4 cause pancreatic cell proliferation. Some of the proliferating cells become PDX-1 positive. These, in turn, depending on the milieu of the PDX-1-containing cells, become endocrine cells.

The acinar cell line AR42J was chosen as the model to examine the ability of GLP-1 and exendin- 4 to cause the differentiation of putative pancreatic precursor cells into islet cells (Zhou et al., 1999). They are derived from a chemically induced rat pancreatic tumor (Rosewicz et al., 1992) and have the potential to be convertcd into cndocrine (Mashima et al., 1996) or exocrine cells (Christophe, 1994). AR42J cells do not express the islet hormones, insulin, glucagon, and pancreatic polypeptide under usual culture conditions. Upon treatment with both GLP-1 (10 nM) and exendin-4 $(0.1 \mathrm{nM})$ for 3 days, 20 percent of the cells were positive for insulin and 50 percent were glucagon positive. While the percentage of glucagon-positive cells began to decrease on the fourth day, the number of insulin-positive cells remained the same during this time. The extent of 5'-bromo- 
$2^{\prime}$-deoxyuridine (BrdU) incorporation was used to measure proliferation of the cells. In untreated cells, 60 percent of the population were dividing but, after 3 days, only 12 percent of the cells were in S phase. Hence, GLP-1 reduced replication in a greater proportion of the cells than were staining positive for the endocrine hormones. The mRNA transcripts of insulin, glucagon, pancreatic polypeptide, glucokinase, and GLUT2 were detected upon reverse transcriptionpolymerase chain reaction (RT-PCR) analysis of total RNA extracts of the treated cells. None of these transcripts were present in the samples extracted from AR42J cells under usual culture conditions. Protein expression of another important $\beta$-cell transcription factor, Neuro D/Beta 2, was only evident in treated cells. When the cells were co-incubated with either GLP-1 or exendin- 4 and the antagonist exendin (9-39), there was no conversion; hence, the differentiation process occurs via direct activation of the GLP-1 G-coupled protein receptor in the case of both peptides. Finally, although PDX-1 normally is present in cells, expression of the protein was enhanced 1.7-fold as a consequence of exendin-4 treatment.

\section{Conclusion}

Our interest in GLP-1 began with an investigation of the compound as an insulin secretagogue. Our observations of the prolonged effect of GLP- 1 following chronic treatment and the reprise of glucose responsivity in the $\beta$-cells of old animals led us to investigate the regulation of key $\beta$-cell transcription factors by GLP-1. We showed that GLP-1 upregulates the master $\beta$-cell transcription factor PDX-1. Our evidence indicates that elevation of this transcription factor is a key element in $\beta$-cell differentiation as induced by GLP-1 and exendin- 4 . Thus, we have uncovered a new benefit to chronic treatment with these peptides. The discovery of GLP-1- and exendin-4-induced $\beta$-cell neogenesis has implications for the use of these peptides in the treatment of the diabetic condition.

\section{REFERENCES}

Ahlgren, U., Jonsson, J., Jonsson, L., Simu, K, and Edlund, H. (1998). Genes Devel. 12, 1763-1768.

Beguin, P., Nagashima, K., Nishimura, M., Gonoi, T., and Seino, S. (1999). EMBO J. 18, 4722-4732.

Bode, H.-P., Moorman, B., Dabew, R., and Goke, B. (1999). Endocrinology 140, 3919-3927.

Bonner-Weir, S., Baxter, L.A., Schuppin, G.T., and Smith, F.E. (1993). Diabetes 42, 1715-1720.

Buteau, J., Roduit, R., Susini, S, and Prentki, M. (1999). Diabetologia 42, 856-864

Centers for Disease Control and Prevention. (1998). "National Diabetes Fact Sheet: National Estimates and General Information on Diabetes in the U.S." (rev. edit.). U.S. Department of Health and Human Services, Atlanta, Ga.

Chen, Y.E., and Drucker, D.J. (1997). J. Biol. Chem. 272, 4108-4115.

Christophe, J. (1994). Am. J. Physiol. 266, G963-G971.

Chua, S.C., Jr., White, D.W., Wu-Peng, S., Liu, S.-M., Okada, N., Kershaw, E.E., Chung, W.K., Power-Kehoe, L., Chua, M., Tartaglia, L.A., and Leibel, R.L. (1996). Diabetes 45, 1141-1143. 
De Ore, K., Greig, N.H., Holloway, H.W., Wang, Y., Perfetti, R., and Egan, J.M. (1997). J. Gerontol. A Biol. Sci. Med. Sci. 52, B245-B249.

Drucker, D.J. (1998). Diabetes 47, 159-169.

Drucker, D.J., Philippe, J., Mojsov, S., Chick, W.L., and Habener, J.F. (1987). Proc. Natl. Acad. Sci. U.S.A. 84, 3434-3438.

Egan, J.M., Asplin, C.M., Drumheller, M.A., Kerrigan, J.R., Scott, J., Martha, P.M., Jr., and Evans, W.S. (1991). Proc. Soc. Exp. Biol. Med. 196, 203-209.

Egan, J.M., Clocquet, A., and Elahi, D. (1999). Diabetologia 42, 148A (abstract).

Elahi, D., McAloon-Dyke, M., Fukagawa, N.K., Meneilly, G.S., Sclater, A.L., Minaker, K.L., Habener, J.F., and Anderson, D.K. (1994). Regul. Peptides 51, 63-74.

Eng, J., Kleinman, W.A., Singh, G., and Raufman, J.P. (1992). J. Biol. Chem. 267, 7402-7405.

Fehmann, H.C., Goke, R., and Goke, B. (1992). Mol. Cell. Endocrinol. 85, C39-C44.

Fehmann, H.C., Goke, R., and Goke, B. (1995). Endocr. Rev. 16, 390-410.

Goke, R., Fehmann, H.-C., Linn ,T., Schmidt, H., Krause, M., Eng, J., and Goke, B. (1993). J. Biol. Chem. 268, 19650-19655.

Greig, N.H., Holloway, H.W., De Ore, K.A., Jani, D., Wang, Y., Zhou, J., Garant, M.J., and Egan, J.M. (1999). Diabetologia 42, 45-50.

Gromada, J., Holst, J.J., and Rorsman, P. (1998). Pflugers Arch. 435, 583-594.

Gu, D., Lee, M.S., Krahl, T., and Sarvetnick, N. (1994). Development 120, 1873-1881

Gutniak, M., Ørskov, C., Holst, J.J., Ahren, B., and Efendic, S. (1992). N. Engl. J. Med. 326, 1316-1322.

Harris, M.I., Flegal, K.M., Cowie, C.C., Fherhardt, M.S., Goldstein, D.F., I.ittle, R.R., Wiedmeyer, H.M., and Byrd-Holt, D.D. (1998). Diabetes Care 21, 518-524

Holz, G.G., Kuhtreiber, W.M., and Habener, J.F. (1993). Nature 361, 362-365.

Hupe-Sodmann, K., McGregor, G.P., Bridenbaugh, R., Goke, R., Goke, B., Thole, H., Zimmermann, B., and Voigt, K. (1995). Regul. Peptides 58, 149-156.

Jahn, R., and Sodhof, T.C. (1999). Annu. Rev. Biochem. 68, 863-911.

Jonsson, J., Carlsson, L., Edlund, T., and Edlund, H. (1994). Nature 371, 606-609.

Komatsu, R., Matsuyama ,T., Namba, M., Watanabe, N., Itoh, H., Kono, N., and Tarui, S. (1989). Diabetes 38, 902-905.

Macfarlane, W.M., Read, M.L., Gilligan, M., Bujalska, I., and Docherty, K. (1994). Biochem. J. 303, 625-631.

Mashima, H., Ohnishi, H., Wakabayashi, K., Mine, T., Miyagawa, J.-I., Hanafusa, T., Seno, M., Yamada, H., and Kojima, I. (1996). J. Clin. Invest. 97, 1647-1654.

Mentlein, R. (1999). Regul. Peptides. 85, 9-24.

Mojsov, S., Heinrich, G., Wilson, I.B., Ravazzola, M., Orci, L., and Habener, J.F. (1986). J. Biol. Chem. 261, 11880-11889.

Montrose-Rafizadeh, C., Egan, J.M., and Roth, J. (1994). Endocrinology 135, 589-594.

Montrose-Rafizadeh, C., Wang, Y., Janczewski, A.M., Henderson, T.E., and Egan, J.M. (1997). Mol. Cell. Endocrinol.130, 109-117.

Nathan, D.M., Schreiber, E., Fogel, H., Mojsov, S., and Habener, J.F. (1992). Diabetes Care 15, 270-276.

Olson, L.K., Sharma, A., Peshavaria. M., Wright, C.V., Towle, H.C., Rodertson, R.P., and Stein, R. (1995). Proc. Natl. Acad. Sci. U.S.A. 92, 9127-9131.

Perfetti, R., Rafizadeh, C.M., Liotta, A.S., and Egan, J.M., (1995). Am. J. Phys. Endocrinol. Meiab. 32, E983-E990.

Perfetti, R., Wang, Y., Shuldiner, A.R., and Egan, J.M., (1996). Gerontol. A Biol. Sci. Med. Sci. 51, B331-B336.

Perfetti, R., Zhou, J., Doyle, M.E., and Egan, J.M. (2000). Endocrinology 141, in press.

Petersen, H.V., Serup, R., Leonard, J., Michelsen, B.K., and Madsen, O.D. (1994). Proc. Natl. Acad. Sci. U.S.A. 91, 10465-10469. 
Pohl, M., and Wank, S.A. (1998). J. Biol. Chem. 273, 9778-9784.

Porzio, O., Marlier, L.N., Federici, M., Hribal, M.L., Magnaterra, R., Lauro, D., Fusco, A., Sesti, G., Borboni, P. (1999). Mol. Cell. Endocrinol. 153, 155-161

Reaven, E.P., Gold, G., and Reaven, G.M. (1979). J. Clin. Invest. 64, 591-599.

Renstrom, E., Eliasson, L., and Rorsman, P.J. (1997). J. Physiol. (Lond). 502, 105-118.

Rosewicz, S., Riecken, E.O., and Wiedenmann, B. (1992). Clin. Invest. 70, 205-209.

Sadoul, K., Lang, J., Montecucco, U., Regazzi, R., Catsicas, S., Wolheim, C.B., and Halban P.A. (1995). J. Cell Biol. 128, 1019-1028.

Sharma, A., Zangen, D.H., Reitz, P., Taneja, M., Lissauer, M.E., Miller, C.P., Weir, G.C., Habener, J.F., and Bonner-Weir, S. (1999). Diabetes 48, 507-513.

Stoffers, D.A., Kieffer, T.J., Hussain, M.A., Drucker, D.J., Bonner-Weir, S., Habener, J.F., and Egan, J.M. (2000). Diabetes 49, 741-748.

Szayna, M., Doyle, M.E., Betkey, J.A., Holloway, H.A., Spencer, R.G.S., Greig, N.H., and Egan, J.M. (2000). Endocrinology 141, 1936-1941.

Thorens, B., Porret, A., Bühler, L., Deng, S.P., Morel, P., and Widmann, C. (1993). Diabetes 42 , 1678-1682

United Kingdom Prospective Diabetes Study. (1995). Diabetes 44, 1249-1258.

United Kingdom Prospective Diabetes Study. (1998). Lancet 352, 837-853.

Waeber, G., Thompson, N., Nicod, P., and Bonny, C. (1996). Mol. Endocrinol. 10,1327-1334.

Wang, X., Cahill, C.M., Pineyro, M.A., Zhou, J., Doyle, M.E., and Egan, J.M. (1999). Endocrinology 140, 4904-4907.

Wang, Y., Egan, J.M., Raygada, M., Nadiv, O., Roth, J., and Montrose-Rafizadeh, C. (1995). Endocrinology 136, 4910-4917.

Wang, Y., Perfetti, R., Greig, N.H., Holloway, H.W., DeOre, K.A., Montrose-Rafizadeh, C., Elahi, D., and Egan, J.M. (1997). J. Clin. Invest. 99, 2883-2889.

Watada, H., Kajimoto, Y., Miyagawa, J., Hanafusa, T., Hamaguchi, K., Matsuoka, T., Yamamoto, K., Matsuzawa, Y., Kawamori, R., and Yamasaki, Y. (1996a). Diabetes 45,1826-1831.

Watada, H, Kajimoto, Y., Kaneto, H., Matsuoka, T., Fujitani, Y., Miyazaki, J., and Yamasaki, Y. (1996b). Biochem. Biophys. Res. Commun. 229, 746-751.

Xu, G., Stoffers, D.A., Habener, J.F., and Bonner-Weir, S. (1999). Diabetes 48, 2270-2276

Yada, T., Itoh, K., and Nakata, M. (1993). Endocrinology 133, 1685-1692.

Young, A.A., Gedulin, B.R., Bhavsar, S., Bodkin, N., Jodka, C., Hansen, B., and Denaro, M. (1999). Diabetes 48, 1026-1034.

Zhou, J., and Egan, J.M. (1997). Biochem. Biophys. Res. Commun. 238, 297-300.

Zhou, J., Wang, X., Pineyro, M.A., and, Egan, J.M. (1999). Diabetes 48, 2358-2366. 
